\title{
Prostate Disease Risk Factors among a New Zealand Cohort
}

\author{
Nishi Karunasinghe ${ }^{a}$ Dug Yeo Han ${ }^{b}$ Megan Goudie ${ }^{c}$ Shuoton Zhu ${ }^{a}$ \\ Karen Bishop ${ }^{a}$ Alice Wang $^{a}$ He Duan $^{a}$ Katja Lange $^{b}$ Sarah Ko ${ }^{b}$ \\ Roxanne Medhora ${ }^{b}$ Shiu Theng Kan ${ }^{b}$ Jonathan Masters ${ }^{c}$ \\ Lynnette R. Ferguson ${ }^{a}$, b \\ ${ }^{a}$ Auckland Cancer Society Research Centre and ${ }^{b}$ Discipline of Nutrition, Faculty of Medical \\ and Health Sciences, The University of Auckland, and ' Urology Department, Auckland \\ Hospital, Auckland, New Zealand
}

\section{Key Words}

Prostate disease · Smoking · Selenium · Age - Single nucleotide polymorphisms .

Glutathione peroxidase activity · Thioredoxin reductase activity

\begin{abstract}
Background: Prostate cancer is a leading public health burden worldwide, and in New Zealand it is the most commonly registered cancer and the third leading cause of cancer deaths among males. Genetic variability and its associations with diet, demographic and lifestyle factors could influence the risk of this disease. Methods: The single nucleotide polymorphisms (SNPs) within a group of antioxidant genes and related markers were tested between patient and control cohorts, adjusted for significant differences between basic lifestyle and demographic characteristics. Results: Increasing age, smoking and low serum selenium levels were significantly associated with an increased risk for prostate disease. Alcohol consumption increased the glutathione peroxidase (GPx) activity. A significant reduction in alcohol consumption was recorded with prostate disease. Three SNPs, namely GPX1 rs1050450, SEL15 rs5845 and CAT rs1001179, were significantly associated with prostate disease risk. A cumulative risk of prostate cancer was noted with 6 risk alleles. A lower GPx activity was recorded with prostate disease compared to the controls. However, the GPx1 rs1050450 allele T in association with prostate cancer recorded a significantly higher GPx activity compared to the controls. Conclusions: These data point to a possibility of identifying individuals at risk of prostate cancer for better management purposes.




\section{Introduction}

Prostate cancer is a leading public health burden worldwide, and in New Zealand it is the most commonly registered cancer among males, making up 28\% of all male cancer registrations, and the third leading cause of cancer deaths among males [1]. Some hereditary risk loci have been linked to the disease [2-7]; however, they are not as aggressive or as predictive as the breast cancer type 1 susceptibility protein (BRCA1) or the adenomatous polyposis coli gene $(A P C)$ in colon cancer. Due to its high prevalence, long latency, hormonal dependency and the ability to monitor with markers such as PSA, prostate cancer is a good candidate for studies on primary prevention [8]. Dietary modification of the disease including disease initiation, progression and severity has also been reported [9-11].

The well-known Nutritional Prevention of Cancer study showed beneficial effects of 200 $\mu \mathrm{g} /$ day selenium (Se) as selenised yeast against several cancers, including prostate cancer, in a group of US men [9]. A meta-analysis of 11 cohort studies and 5 case-control studies carried out by Etminan et al. [12] indicated a decrease in the pooled relative risk of prostate cancer among those with moderate Se intakes compared with those with low intakes. However, a large study with over 32,000 US men failed to show beneficial effects of $200 \mu \mathrm{g} /$ day Se supplemented as selenomethionine [13]. High baseline serum Se levels and the use of selenomethionine instead of selenised yeast are considered the major causes of this discrepancy, that may have caused a lack of cancer protection/reduction effects. Among the other possible reasons could be the degree of genetic variability among different cohorts analysed. The prostate disease risk variability among selenogenome in humans, with a range of functional differences, is thus worth investigating. The GPx1 rs1050450 C>T single nucleotide polymorphism (SNP) occurs within exon 1 of the GPx1 gene and forms structurally different subunits containing either prolein or leucine at codon 198 [14]. Located in the 3' UTR near the selenocysteine (Sec) insertion sequence element, the GPx 4 rs $713041 \mathrm{C}>\mathrm{T}$ polymorphism can modulate GPx 4 activity by altering Sec insertion and the protein binding to the $3^{\prime}$ UTR [15]. Selenoprotein P is presented in two isoforms in human plasma where the production of the Se-rich $60-\mathrm{kDa}$ isoform is favoured by the major allele G of SEPP1 rs3877899 while allele A favours the 50-kDa isoform $[16,17]$. This is probably an evolutionary adaptation for survival in low Se environments. The SEL15 gene is involved in protein folding pathways, and differential Se incorporation among SEL15 rs5845 C and T alleles has been reported [18]. According to Curran et al. [19], the G allele of the SELS rs28665122 SNP is required to produce sufficient promoter activity in the presence of a stress stimulator, whereas the A allele shows significantly lower activity. It therefore seemed appropriate to look at the prostate cancer risk modulation with the level of serum Se, body mass index (BMI), smoking status and alcohol consumption. This analysis further investigates the effect of SNPs related to Se metabolism and antioxidant defence in modulating prostate disease risk as well as the effects on activity levels of two major antioxidant selenoenzymes - glutathione peroxidase (GPx) and thioredoxin reductase (TR) - among patient and control cohorts. The Se metabolism-related SNPs considered here are GPx1 rs1050450, GPx4 rs713041, SEPP1 rs3877899, SEL15 rs5845, SELS rs28665122 and SELS rs4965373. Among the other antioxidant pathway-related SNPs considered here are catalase (CAT) rs1001179 and manganese superoxide dismutase SOD2 rs4880.

\section{Methods}

\section{Study Population}

Prostate cancer patient recruitment was carried out with the informed consent of the patients, and the recruitment took place through the Department of Urology, Auckland Hospital, covering Auckland, North Shore and Manukau centres (ethics ref. NTY/05/06/037). The patients identified from the registry of the Department 
of Urology were sent an invitation of participation for the study. Approximately $25 \%$ of the patients responded to the invitation. Similarly, patients with benign prostate hyperplasia and with negative biopsies for prostate cancer were also recruited with their informed consent. The control subjects were from the general public in the Auckland region, who responded to public advertisements made through media, New Zealand Blood Services and e-mails circulated through the University of Auckland. Participants who have self-reported that they do not carry urological problems or have no history of cancers except for skin cancers are considered here as the control group. They are part of the volunteers recruited with informed consent for the Se supplementation trial carried out by the Discipline of Nutrition, University of Auckland (ethics ref. NTY/06/07/060).

Our patient and control database consisted of 868 subjects within the age range of $40-81$ years. A total of $838(96.5 \%)$ of them self-reported a European ancestry. Additionally, the database included 11 patients (1.3\%) reporting a Maori and Pacific ethnicity, 6 patients (0.7\%) of Asian and 13 (1.5\%) of Indian/Middle Eastern ethnicities. According to a meta-analysis performed by Chen et al. [20], Asian populations show a significantly lower mean frequency for minor allele $\mathrm{T}$ of GPx1 rs1050450 (0.06) compared to Europeans (0.30). The Asian population in our database had a zero T allele frequency, while the Maori and Pacific populations showed a frequency of 0.04 , similar to that of Asian populations reported by Chen et al. [20]. The Indian and Middle Eastern group had a $\mathrm{T}$ allele frequency of 0.25 , which is within the range reported for Europeans [20]. Therefore, the current subject selection for the analysis was based on the GPx1 rs1050450 $\mathrm{T}$ allele frequency distribution (similar to that of Europeans reported by Chen et al.) and included subjects self-reporting as Indian sub-continent and Middle Eastern origins, along with those reporting a European origin. A total of 851subjects, 275 with malignant disease, 135 with benign prostate disease and 441 healthy controls, are included in this study.

\section{Collection of Demographic and Lifestyle Data}

The heights and weights of the patients were measured during their clinical appointments, while the same was done with the control population at their recruitment to the Se supplementation study. Both patients and controls were asked to complete a lifestyle questionnaire that was used to collect information on tobacco smoking habits and alcohol intake.

\section{Blood Collection and Processing}

At the entry to the study, blood samples from each volunteer were collected in each of an EDTA, heparin and plain Vacutainer ${ }^{\circledR}$ tube from Becton Dickinson. An aliquot of the EDTA sample was subsequently used for DNA extraction. Total genomic DNA was extracted from blood with the QIAamp DNA Blood Mini Kit (Qiagen) according to the manufacturer's instructions, using a fully automated procedure on the QIAcube.

\section{SNP Genotyping}

The TaqMan ${ }^{\circledR}$ SNP Genotyping Assay from Applied Biosystems was used for the SNP genotyping of the panel of genes selected in this study. The assays were obtained either pre-designed from Applied Biosystems or custom-made through Assay-by-Design service by ABI. TaqMan assays were optimized with 24 samples consisting of 20 reference Centre d'Etude du Polymorphisms Humain (CEPH) samples with known genotypes from the HapMap project [21] and 4 blanks. A total of 8 HapMap controls were also included with each reaction plate. The call rate for each SNP genotype determination was over $95 \%$. The reactions were prepared using 2× TaqMan Universal Master Mix, 40× SNP Genotyping Assay Mix, DNase-free water and 10 ng genomic DNA in a final volume of $5 \mu \mathrm{l}$ per reaction. The PCR amplification was performed using the ABI Prism 7900 HT Fast Real-Time PCR sequence detector machine under the following conditions for both test samples and HapMap controls: $10 \mathrm{~min} 95^{\circ} \mathrm{C}$ enzyme activation followed by 40 cycles at $92^{\circ} \mathrm{C}$ for $15 \mathrm{~s}$ and $60^{\circ} \mathrm{C}$ for $1 \mathrm{~min}$ (annealing/extension). The allelic discrimination results were determined after the amplification by performing an end point reading.

\section{Serum Se}

The blood collected in the plain Vacutainer tube was spun at 2,000 $\mathrm{g}$ for $10 \mathrm{~min}$ at $4{ }^{\circ} \mathrm{C}$ to separate the serum. Serum Se levels were assayed at Gribbles Veterinary Pathology, Hamilton, using a modified semiautomated fluorometric assay based on methods reported by Rongpu et al. [22], Watkinson [23] and Watkinson and Brown [24]. The fluorescence of the final benzopiazselenol extracted into cyclohexane was measured with an excitation wave length of $360 \mathrm{~nm}$ and an emission wave length of $518 \mathrm{~nm}$. A pooled human control serum sample was administered with each batch of samples tested for Se levels. Se measurement on this sample showed an interassay coefficient of variation of $9.9 \%$. 


\section{Selenoenzyme Activities}

GPx and TR activities were measured in a subset of samples following procedures given in Karunasinghe et al. [25]. Briefly, erythrocyte lysates were prepared from $100 \mu$ aliquots of EDTA blood, as described for the Calbiochem Cellular glutathione peroxidase assay kit (catalog No. 354104). The conversion of the haemolysates to cyanomethemoglobin using a transformation solution was also carried out before the enzyme activities (both GPx and TR) were measured. GPx activity was assayed using the protocol of Wendel [26], modified to suit a 96-well plate format, and the samples were assayed in duplicate. The spectrophotometric measurements were carried out for $4 \mathrm{~min}$ at $366 \mathrm{~nm}$ using the kinetic protocol on a Multiskan spectrophotometer (Thermo Scientific). For GPx activity assay, each well contained an equivalent of $250 \mathrm{mg}$ haemoglobin. One unit of GPx activity is defined as $1 \mathrm{mmol}$ NADPH oxidized per minute at $37^{\circ} \mathrm{C}$. A standard solution of glutathione peroxidase from bovine erythrocytes (Sigma catalog No. G6137), diluted 400-fold according to the manufacturer's instructions, was used as a positive control to assure the reaction was working and to estimate inter- and intra-experiment variation. The inter- and intra-assay coefficients of variation were 8.62 and $3.16 \%$, respectively. TR activity was assayed using the protocol of Smith and Levander [27], with $20 \mathrm{mmol}$ of aurothiomalate (Sigma Aldrich 157201) instead of aurothioglucose as the suppressor of TR for the measurement of non-TR related-activities. Each well contained an equivalent of 125 mg haemoglobin, and the samples were assayed in duplicate. Data collection was commenced 1 min after the initiation of the reaction to allow for a non-enzymatic reduction of 5,5'-dithiobis(2-nitrobenzoic acid) to go to completion. One unit of TR activity is defined as $1 \mathrm{mmol} 5$-thio-2-nitrobenzoic acid formed per minute at $37^{\circ} \mathrm{C}$. All spectrophotometric measurements were carried out for $4 \mathrm{~min}$ at $412 \mathrm{~nm}$ using the kinetic protocol on a Multiskan spectrophotometer (Thermo Scientific). Rat recombinant TR from IMCO, Sweden (catalog No. TR03), diluted 100-fold in milliQ water, was used as a positive control to ensure the reaction was working and to estimate inter- and intra-experiment variation. The inter- and intra-assay coefficients of variation were 5.11 and $4.88 \%$, respectively.

\section{Statistical Analysis}

Since the serum Se concentrations were the log-transformed values, the estimated actual values were determined by utilizing the exponential (anti-log) function and will be hereafter referred to as serum Se level. The differences among the confounding variables, including age, BMI, alcohol consumption, smoking status and serum Se levels, were tested between the prostate cancer patient group, patients with benign urology disease and/or controls (table 1). These confounding variables, with the exception of BMI (as the BMI was not significantly different among these three groups (table 1), were adjusted for the SNP analyses. There was no significant difference between the odds ratios (ORs) from current and former smokers on either malignant $(p=0.7364)$ or benign $(p=0.3531)$ disease compared to controls. Therefore, these two groups were combined and considered as ever-smokers for further SNP analysis. SNPs were analysed using the additive model (count of the number of the tested allele: 0,1 and 2). The assessment of the risk of incident prostate cancer association with SNPs was carried out by a logistic regression model with adjustments for the confounding variables. The genetic risk score (GRS) was calculated using 7 of the candidate SNPs studied in this study. The missing genotype rate of SELS rs28665122 was 8.7\%; therefore, it was excluded from the GRS construction. The GRS ranged from 0 to 14 on the basis of the number of tested alleles. All analyses were carried out using R statistical software [28] and SAS (V9.2 SAS Institute, Cary, N.C., USA).

\section{Results}

Demographic characteristics of the study group and their associations with prostate disease are given in table 1 . Tobacco smoking was found to be a lifestyle factor significantly related to an increased risk of prostate cancer $(\mathrm{OR}=1.79)$ when patient lifestyle factors were compared to those of healthy controls $(\mathrm{p}=0.0065)$. The reported alcohol consumption produced a significant risk reduction in both the benign $(\mathrm{OR}=0.48, \mathrm{p}=4.83 \mathrm{E}-06)$ and malignant $(\mathrm{OR}=0.37, \mathrm{p}=8.84 \mathrm{E}-04)$ disease groups compared to controls, while alcohol intake showed a marginal non-significant increase in BMI across all subjects (data not shown). However, no significant increase in prostate cancer or benign prostate disease risk was observed with BMI ( $\mathrm{p}=0.534$ and $\mathrm{p}=0.916$, respectively). We also observed individuals with 
Table 1. Demographic and lifestyle characteristics of the study group and their association with prostate disease

\begin{tabular}{|c|c|c|c|}
\hline & $\begin{array}{l}\text { Malignant } \\
(\mathrm{n}=275,32.3 \%)\end{array}$ & $\begin{array}{l}\text { Benign } \\
(\mathrm{n}=135,15.9 \%)\end{array}$ & $\begin{array}{l}\text { Healthy controls } \\
(\mathrm{n}=441,51.8 \%)\end{array}$ \\
\hline \multicolumn{4}{|c|}{ Current alcohol consumption } \\
\hline No, n (\%) & $75(46.0)$ & $31(19.0)$ & $57(35.0)$ \\
\hline Yes, n (\%) & $189(28.1)$ & $100(14.9)$ & $384(57.0)$ \\
\hline OR $(95 \% \mathrm{CI})$ & $0.37(0.25-0.55)$ & $0.48(0.29-0.78)$ & 1.00 \\
\hline \multirow{2}{*}{\multicolumn{4}{|c|}{$\begin{array}{l}\text { pvarue } \\
\text { Past or current smoking status* }\end{array}$}} \\
\hline & & & \\
\hline No, n (\%) & $127(26.9)$ & $73(15.4)$ & $273(57.7)$ \\
\hline Yes, n (\%) & $140(37.9)$ & $61(16.5)$ & $168(45.5)$ \\
\hline OR $(95 \% \mathrm{CI})$ & $1.79(1.32-2.44)$ & $1.36(0.92-2.01)$ & 1.00 \\
\hline $\mathrm{p}$ value & 0.0065 & 0.9395 & \\
\hline \multicolumn{4}{|l|}{ Se level, $\mathrm{ng} / \mathrm{ml}$} \\
\hline Mean $\pm \mathrm{SE}$ & $101.2 \pm 1.01$ & $100.7 \pm 1.02$ & $112.9 \pm 1.01$ \\
\hline Range & $52.1-206.9$ & $62.0-165.8$ & $63.2-304.8$ \\
\hline Estimate $(95 \% \mathrm{CI})$ & $0.90(0.87-0.92)$ & $0.89(0.86-0.93)$ & 1.00 \\
\hline $\mathrm{p}$ value & $2.49 \mathrm{E}-12$ & 4.27E-09 & \\
\hline \multicolumn{4}{|l|}{ BMI } \\
\hline Mean $\pm \mathrm{SE}$ & $27.2 \pm 0.25$ & $27.0 \pm 0.36$ & $27.0 \pm 0.19$ \\
\hline Range & $16.7-40.8$ & $16.8-39.1$ & $17.2-44.8$ \\
\hline Estimate $(95 \% \mathrm{CI})$ & $0.20(-0.41-0.81)$ & $-0.04(-0.83-0.74)$ & 0 \\
\hline \multirow{2}{*}{\multicolumn{4}{|c|}{$\begin{array}{l}\mathrm{p} \text { value } \\
\text { Age at recruitment, years }\end{array}$}} \\
\hline & & & \\
\hline Mean \pm SE & $66.3 \pm 0.48$ & $66.6 \pm 0.60$ & $57.4 \pm 0.49$ \\
\hline Range & $45.4-80.9^{\dagger}$ & $41.7-80.9^{\dagger}$ & $40.0-81.0$ \\
\hline $\mathrm{p}$ value & $<0.0001$ & & \\
\hline
\end{tabular}

* Current $(n=34)$ and past $(n=335)$ smokers were combined due to no significant difference in prostate disease risk between the two groups ( $p=0.4941)$.

${ }^{\dagger}$ The mean difference between the age at recruitment and the date of diagnosis with the disease was 0.31 years $(\mathrm{SD}=0.72)$.

either benign or malignant disease having a significantly $(p=4.27 \mathrm{E}-09$ and $p=2.49 \mathrm{E}-12$, respectively) lower serum Se level compared to controls (table 1).

Although the patient and control cohorts were selected according to an age range of $40-81$ years, the controls were significantly younger than the patients $(\mathrm{p}<0.001)$ (table 1$)$. Therefore, we adjusted the data for age in the subsequent analyses along with the adjustments for other confounding variables.

\section{Association of Confounding Variables and Antioxidant Enzyme Levels}

Alcohol consumption was positively and significantly $(\mathrm{p}=0.002)$ associated with GPx activity in the overall study cohort, although age, BMI and smoking status showed no such association (table 2).

\section{Association of Health Status and Antioxidant Enzyme Levels}

Patients with malignant and benign urology diseases showed a significantly lower level of GPx activity compared to controls ( $\mathrm{p}=0.033$ and $\mathrm{p}=0.011$, respectively) before data were adjusted for alcohol consumption. This association remained significant among those with benign urology disease after the data were adjusted for alcohol consumption $(p=0.027)$ (table 3). 
Table 2. Variation of selenoenzyme activities with demographic and lifestyle factors in the overall study group

\begin{tabular}{|c|c|c|c|c|}
\hline & \multicolumn{2}{|l|}{ GPx activity } & \multicolumn{2}{|l|}{ TR activity } \\
\hline & estimate $(95 \% \mathrm{CI})$ & $\mathrm{p}$ & estimate $(95 \% \mathrm{CI})$ & $\mathrm{p}$ \\
\hline Age & $0.033(-0.017$ to 0.082$)$ & 0.194 & $0.003(-0.003$ to 0.009$)$ & 0.293 \\
\hline BMI & $0.092(-0.048$ to 0.232$)$ & 0.197 & $0.003(-0.014$ to 0.019$)$ & 0.735 \\
\hline \multicolumn{5}{|c|}{ Current alcohol consumption } \\
\hline Yes & $2.16(0.79$ to 3.52$)$ & 0.0019 & $0.056(-0.103$ to 0.215$)$ & 0.490 \\
\hline No & 0 & & 0 & \\
\hline \multicolumn{5}{|c|}{ Ever smoked } \\
\hline Yes & $-0.21(-1.27$ to 0.85$)$ & 0.693 & $0.037(-0.085$ to 0.160$)$ & 0.554 \\
\hline No & 0 & & & \\
\hline
\end{tabular}

Table 3. Variation of selenoenzyme activities in a subset of subjects with malignant and benign urology diseases compared to controls

\begin{tabular}{|c|c|c|c|c|c|c|}
\hline & & \multirow[t]{2}{*}{ Mean \pm SE } & \multicolumn{2}{|l|}{ Before adjustment } & \multicolumn{2}{|l|}{ After adjustment* } \\
\hline & & & estimate $(95 \% \mathrm{CI})$ & $\mathrm{p}$ & estimate $(95 \% \mathrm{CI})$ & $\mathrm{p}$ \\
\hline \multirow[t]{3}{*}{ GPx } & Benign $(n=86)$ & $13.0 \pm 0.61$ & $-0.011(-3.609$ to -1.475$)$ & 0.0107 & $-1.180(-3.352$ to -0.207$)$ & 0.0266 \\
\hline & Malignant (n=136) & $13.6 \pm 0.48$ & $-0.033(-2.722$ to -0.112$)$ & 0.0334 & $-1.133(-2.450$ to 0.184$)$ & 0.0916 \\
\hline & Control $(n=431)$ & $15.0 \pm 0.35$ & 0.00 & & 0.00 & \\
\hline \multirow[t]{3}{*}{ TR } & Benign $(n=84)$ & $1.12 \pm 0.09$ & $0.576(-0.131$ to 0.236$)$ & 0.5763 & & \\
\hline & Malignant $(\mathrm{n}=132)$ & $1.12 \pm 0.06$ & $0.037(-0.117$ to 0.190$)$ & 0.6389 & & \\
\hline & Control (n = 427) & $1.08 \pm 0.04$ & 0.00 & & & \\
\hline
\end{tabular}

* Adjustments were made for alcohol consumption.

\section{Se and Anti-Oxidant Metabolism-Related Genes}

The SNP genotype frequencies recorded among malignant and benign patients and healthy controls are given in table 4, and the risk associations between SNP genotypes are given in table 5. Individuals with GPx1 rs1050450 minor allele T had a significantly higher prostate cancer risk as compared to controls $(\mathrm{OR}=1.38, \mathrm{p}=0.02)$ after adjustment for the confounding factors. The risk of malignant disease was also significant compared to benign disease among those carrying the $C A T$ rs1001179 minor allele T before $(O R=1.55, \mathrm{p}=0.022)$ and after $(\mathrm{OR}=1.61, \mathrm{p}=0.015)$ adjustment for the confounding variables. Individuals with the minor allele $\mathrm{T}$ of the SEP15 rs5845 were at significant risk of having benign disease compared to controls ( $\mathrm{OR}=1.77, \mathrm{p}=0.0003)$, and this remained significant after adjustment for the confounding factors $(\mathrm{OR}=1.98, \mathrm{p}=0.0001)$. Those with this allele also showed a lower risk of malignancies compared to benign disease $(\mathrm{OR}=0.63, \mathrm{p}=0.006)$, and this remained significant after adjustment for the confounding variables (OR $=0.62, p=0.005$ ). The estimated GRS indicated a significantly increased risk of malignancies due to the cumulative effect of the tested alleles compared to controls ( $O R=1.16, p=0.0074)$ (table 5). 
Table 4. Frequency of SNPs associated with Se and other anti-oxidant metabolisms assessed by patient and control subjects

\begin{tabular}{|c|c|c|c|c|c|}
\hline Gene & SNP & Genotype & Malignant & Benign & Controls \\
\hline SELS & rs28665122 & $\begin{array}{l}A / A \\
A / G \\
G / G\end{array}$ & $\begin{array}{l}4(1.7) \\
57(24.6) \\
171(73.7)\end{array}$ & $\begin{array}{l}4(3.2) \\
28(22.1) \\
95(74.8)\end{array}$ & $\begin{array}{l}7(1.7) \\
102(24.4) \\
309(73.9)\end{array}$ \\
\hline$\overline{S E L S}$ & rs4965373 & $\begin{array}{l}\text { A/A } \\
A / G \\
G / G\end{array}$ & $\begin{array}{l}29(11.2) \\
116(44.6) \\
115(44.2)\end{array}$ & $\begin{array}{l}14(11.1) \\
53(42.1) \\
59(46.8)\end{array}$ & $\begin{array}{l}44(10.0) \\
186(42.4) \\
209(47.6)\end{array}$ \\
\hline$\overline{S E P P 1}$ & rs3877899 & $\begin{array}{l}\text { A/A } \\
A / G \\
G / G\end{array}$ & $\begin{array}{l}18(7.0) \\
88(34.0) \\
153(59.1)\end{array}$ & $\begin{array}{l}9(6.8) \\
46(34.9) \\
77(58.3)\end{array}$ & $\begin{array}{l}19(4.4) \\
162(37.2) \\
255(58.5)\end{array}$ \\
\hline$\overline{S E P 15}$ & rs5845 & $\begin{array}{l}\mathrm{C} / \mathrm{C} \\
\mathrm{C} / \mathrm{T} \\
\mathrm{T} / \mathrm{T} \\
\end{array}$ & $\begin{array}{l}160(62.0) \\
84(32.6) \\
14(5.4)\end{array}$ & $\begin{array}{l}67(49.6) \\
52(38.5) \\
16(11.9)\end{array}$ & $\begin{array}{l}270(62.8) \\
145(33.7) \\
15(3.5)\end{array}$ \\
\hline$\overline{G P x 1}$ & rs1050450 & $\begin{array}{l}\mathrm{C} / \mathrm{C} \\
\mathrm{C} / \mathrm{T} \\
\mathrm{T} / \mathrm{T}\end{array}$ & $\begin{array}{l}122(46.6) \\
110(42.0) \\
30(11.5)\end{array}$ & $\begin{array}{l}62(46.3) \\
60(44.8) \\
12(9.0)\end{array}$ & $\begin{array}{l}216(49.7) \\
186(42.8) \\
33(7.6)\end{array}$ \\
\hline$\overline{G P x 4}$ & rs713041 & $\begin{array}{l}\mathrm{C} / \mathrm{C} \\
\mathrm{C} / \mathrm{T} \\
\mathrm{T} / \mathrm{T}\end{array}$ & $\begin{array}{l}84(32.3) \\
129(49.6) \\
47(18.1)\end{array}$ & $\begin{array}{l}44(32.8) \\
68(50.8) \\
22(16.4)\end{array}$ & $\begin{array}{l}144(32.8) \\
210(47.8) \\
85(19.4)\end{array}$ \\
\hline$\overline{C A T}$ & rs1001179 & $\begin{array}{l}\mathrm{C} / \mathrm{C} \\
\mathrm{C} / \mathrm{T} \\
\mathrm{T} / \mathrm{T}\end{array}$ & $\begin{array}{l}144(55.8) \\
99(38.4) \\
15(5.8)\end{array}$ & $\begin{array}{l}92(69.2) \\
35(26.3) \\
6(4.5)\end{array}$ & $\begin{array}{l}258(59.5) \\
160(36.9) \\
16(3.7)\end{array}$ \\
\hline SOD2 & rs4880 & $\begin{array}{l}\mathrm{C} / \mathrm{C} \\
\mathrm{C} / \mathrm{T} \\
\mathrm{T} / \mathrm{T}\end{array}$ & $\begin{array}{l}70(26.8) \\
138(52.9) \\
53(20.3)\end{array}$ & $\begin{array}{l}32(23.9) \\
71(53.0) \\
31(23.1)\end{array}$ & $\begin{array}{l}108(24.6) \\
222(50.5) \\
110(25.0)\end{array}$ \\
\hline
\end{tabular}

Association of Health Status and Gene Polymorphisms with Activity of Selenoenzymes

The GPx1 rs1050450 T allele showed a significantly higher GPx activity among those with prostate cancer compared to controls $(\mathrm{OR}=2.14, \mathrm{p}=0.034$ before adjustment and $\mathrm{OR}=2.13$, $\mathrm{p}=0.034$ after adjustment) (table 6). None of the other gene polymorphisms in association with health status showed any effect on GPx activity. There was also no significant effect on TR activity as a consequence of the polymorphisms studied in association with health status.

\section{Discussion}

A recent review has found that age, race and family history of prostate cancer are established variables in the consideration of prostate cancer risks, while behavioural and lifestyle factors have only weak associations [29]. However, our evaluations have shown that smoking is a lifestyle factor that shows an association with prostate cancer in the current study group. This could be related to tobacco smoke being an established carcinogen that could cause many human cancers [30,31].

The reported alcohol intake showed a significant association with a reduced risk of prostate disease. The lower alcohol intake among those with prostate disease could also be a lifestyle adaptation since diagnosis. A meta-analysis covering over 50 published studies has shown no evidence of an increased prostate cancer risk, even with the highest doses of alcohol intake [32]. 


\section{Nutrigenomics}

Table 5. Prostate cancer and benign urology disease risk association among the subjects based on Se and anti-oxidant pathway-related genes

\begin{tabular}{|c|c|c|c|c|c|c|c|c|}
\hline \multirow[t]{2}{*}{ Gene } & \multirow[t]{2}{*}{ SNP } & \multirow[t]{2}{*}{ Status } & \multirow{2}{*}{$\begin{array}{l}\text { Tested } \\
\text { allele }\end{array}$} & \multirow{2}{*}{$\begin{array}{l}\text { Tested } \\
\text { allele } \\
\text { frequency }\end{array}$} & \multicolumn{2}{|l|}{ Before adjustment } & \multicolumn{2}{|l|}{ After adjustment } \\
\hline & & & & & OR $(95 \% \mathrm{CI})$ & $\mathrm{p}$ & $\% \mathrm{CI})$ & $\mathrm{p}$ \\
\hline \multicolumn{9}{|c|}{ Malignant vs. control } \\
\hline \multirow[t]{2}{*}{ SELS } & rs28665122 & Malignant & G & 0.860 & $0.99(0.71-1.38)$ & 0.9465 & $1.00(0.69-1.45)$ & 0.9987 \\
\hline & & Control & & 0.861 & 1.00 & & 1.00 & \\
\hline \multirow[t]{2}{*}{ SELS } & rs4965373 & Malignant & A & 0.335 & $1.11(0.88-1.40)$ & 0.3848 & $1.14(0.88-1.49)$ & 0.3129 \\
\hline & & Control & & 0.312 & 1.00 & & 1.00 & \\
\hline \multirow[t]{2}{*}{ SEPP1 } & rs3877899 & Malignant & A & 0.239 & $1.06(0.82-1.37)$ & 0.6682 & $1.15(0.8$ & 0.3396 \\
\hline & & Control & & 0.229 & 1.00 & & 1.00 & \\
\hline \multirow[t]{2}{*}{ SEP15 } & rs5845 & Malignant & $\mathrm{T}$ & 0.217 & $1.09(0.83-1.42)$ & 0.5472 & $1.23(0.91-1.67)$ & 0.1736 \\
\hline & & Control & & 0.203 & 1.00 & & 1.00 & \\
\hline \multirow[t]{2}{*}{$G P x 1$} & rs1050450 & Malignant & $\mathrm{T}$ & 0.324 & $1.18(0.93-1.49)$ & 0.1703 & $1.38(1.05-1.80)$ & 0.0196 \\
\hline & & Control & & 0.290 & 1.00 & & 1.00 & \\
\hline \multirow[t]{2}{*}{ GPx4 } & rs713041 & Malignant & $\mathrm{C}$ & 0.571 & $1.02(0.82-1.26)$ & 0.8859 & $0.98(0.77-1.25)$ & 0.8866 \\
\hline & & Control & & 0.567 & 1.00 & & 1.00 & \\
\hline \multirow[t]{2}{*}{$C A T$} & rs1001179 & Malignant & $\mathrm{T}$ & 0.250 & $1.18(0.91-1.54)$ & 0.2082 & $1.29(0.97-1.74)$ & 0.0853 \\
\hline & & Control & & 0.221 & 1.00 & & 1.00 & \\
\hline \multirow[t]{2}{*}{ SOD2 } & rs4880 & Malignant & $\mathrm{C}$ & 0.533 & $1.16(0.93-1.44)$ & 0.2012 & $1.11(0.87-1.42)$ & 0.3956 \\
\hline & & Control & & 0.498 & 1.00 & & 1.00 & \\
\hline \multicolumn{5}{|c|}{ GRS based on 7 SNPs (excluding rs28665122) } & $1.10(1.00-1.20)$ & 0.0558 & $1.16(1.04-1.29)$ & 0.0074 \\
\hline Benig & control & & & & & & & \\
\hline$S E L S$ & rs28665122 & Benign & G & 0.858 & $0.98(0.65-1.46)$ & 0.9044 & $1.00(0.64-1.57)$ & 0.9957 \\
\hline & & Control & & 0.861 & 1.00 & & 1.00 & \\
\hline SELS & rs4965373 & Benign & A & 0.321 & $1.04(0.78-1.41)$ & 0.7799 & $1.04(0.75-1.45)$ & 0.8032 \\
\hline & & Control & & 0.312 & 1.00 & & 1.00 & \\
\hline SEPP1 & rs3877899 & Benign & A & 0.242 & $1.08(0.78-1.49)$ & 0.6554 & $1.08(0.75-1.55)$ & 0.6841 \\
\hline & & Control & & 0.229 & 1.00 & & 1.00 & \\
\hline SEP15 & rs5845 & Benign & $\mathrm{T}$ & 0.311 & $1.77(1.30-2.41)$ & 0.0003 & $1.98(1.40-2.81)$ & 0.0001 \\
\hline & & Control & & & 1.00 & & & \\
\hline GPX1 & rs1050450 & Benign & $\mathrm{T}$ & 0.313 & $1.13(0.83-1.52)$ & 0.4469 & $1.30(0.92-1.84)$ & 0.1342 \\
\hline & & Control & & 0.290 & 1.00 & & 1.00 & \\
\hline GPx4 & rs713041 & Benign & $\mathrm{C}$ & 0.582 & $1.06(0.81-1.40)$ & 0.6680 & $1.07(0.79-1.46)$ & 0.6633 \\
\hline & & Control & & & 1.00 & & & \\
\hline CAT & rs1001179 & Benign & $\mathrm{T}$ & 0.177 & $0.75(0.52-1.07)$ & 0.1144 & $0.74(0.50-1.09)$ & 0.1285 \\
\hline & & Control & & 0.221 & 1.00 & & 1.00 & \\
\hline SOD2 & rs4880 & Benign & $\mathrm{C}$ & 0.504 & $1.03(0.78-1.35)$ & 0.8619 & $0.97(0.72-1.32)$ & 0.8620 \\
\hline & & Control & & 0.498 & 1.00 & & & \\
\hline GRS bas & d on 7 SNPs & excluding rs2 & 8665122 & & $1.07(0.94-1.22)$ & 0.2894 & $7(0.94-1.22)$ & 0.2894 \\
\hline$\overline{M a l i}$ & & & & & & & & \\
\hline SELS & rs28665122 & Malignant & G & 0.860 & $1.01(0.66-1.57)$ & 0.9521 & $0.90(0.58-1.42)$ & 0.6617 \\
\hline & & Benign & & 0.858 & & & & \\
\hline SELS & rs4965373 & Malignant & A & 0.335 & $1.06(0.77-1.46)$ & 0.7163 & $1.09(0.79-1.51)$ & 0.6023 \\
\hline & & Benign & & & & & & \\
\hline SEPP1 & rs3877899 & Malignant & A & 0.239 & $0.98(0.70-1.38)$ & 0.9271 & $1.00(0.71-1.41)$ & 0.9961 \\
\hline & & Benign & & 0.242 & 1.00 & & 1.00 & \\
\hline SEP15 & rs5845 & Malignant & $\mathrm{T}$ & 0.217 & $0.63(0.46-0.88)$ & 0.0057 & $0.62(0.44-0.87)$ & 0.0053 \\
\hline & & Benign & & & & & & \\
\hline$G P \times 1$ & rs1050450 & Malignant & $\mathrm{T}$ & 0.324 & $1.05(0.77-1.44)$ & 0.7555 & $1.07(0.77-1.47)$ & 0.6944 \\
\hline & & Benign & & 0.313 & 1.00 & & 1.00 & \\
\hline GPx4 & rs713041 & Malignant & $\mathrm{C}$ & 0.571 & $0.96(0.71-1.29)$ & 0.7663 & $0.99(0.72-1.35)$ & 0.9330 \\
\hline & & Benign & & & 1.00 & & 1.00 & \\
\hline$C A T$ & rs1001179 & Malignant & $\mathrm{T}$ & 0.250 & $1.55(1.06-2.25)$ & 0.0222 & $1.61(1.10-2.36)$ & 0.0150 \\
\hline & & Benign & & 0.177 & 1.00 & & 1.00 & \\
\hline SOD2 & rs4880 & Malignant & $\mathrm{C}$ & 0.533 & $1.13(0.83-1.53)$ & 0.4283 & $1.12(0.82-1.53)$ & 0.4662 \\
\hline & & Benign & & 0.504 & 1.00 & & 1.00 & \\
\hline GRS ba & on 7 SNPs & excluding $\mathrm{rs}$ & 6 & & $1.02(0.89-1.17)$ & 0.0558 & $1.05(0.91-1.20)$ & 0.5313 \\
\hline
\end{tabular}


Table 6. Association of tested alleles of GPx1 rs1050450 and disease condition with the activity level of selenoenzymes GPx and TR

\begin{tabular}{|c|c|c|c|c|c|c|c|}
\hline & \multirow{2}{*}{$\begin{array}{l}\text { No. of T allele } \\
\text { rs1050450 }\end{array}$} & \multirow{2}{*}{$\mathrm{n}$} & \multirow[t]{2}{*}{ Mean \pm SE } & \multicolumn{2}{|l|}{ Before adjustment } & \multicolumn{2}{|l|}{ After adjustment* } \\
\hline & & & & estimate $(95 \% \mathrm{CI})$ & $\mathrm{p}$ & estimate (95\% CI) & $\mathrm{p}$ \\
\hline Benign & $\begin{array}{l}0 \\
1 \\
2\end{array}$ & $\begin{array}{l}41 \\
34 \\
10\end{array}$ & $\begin{array}{l}13.26 \pm 0.76 \\
12.67 \pm 1.14 \\
12.55 \pm 1.71\end{array}$ & $0.81(-1.52$ to 3.14$)$ & 0.4949 & $1.08(-1.25$ to 3.40$)$ & 0.3622 \\
\hline Malignant & $\begin{array}{l}0 \\
1 \\
2\end{array}$ & $\begin{array}{l}62 \\
58 \\
15\end{array}$ & $\begin{array}{l}13.14 \pm 0.64 \\
14.02 \pm 0.70 \\
14.95 \pm 1.87\end{array}$ & $2.14(0.16$ to 4.11$)$ & 0.0343 & $2.13(0.16$ to 4.10$)$ & 0.0340 \\
\hline Control & $\begin{array}{l}0 \\
1 \\
2\end{array}$ & $\begin{array}{r}213 \\
181 \\
32\end{array}$ & $\begin{array}{l}15.77 \pm 0.51 \\
14.43 \pm 0.52 \\
13.46 \pm 1.26\end{array}$ & 0.0 & & 0.0 & \\
\hline
\end{tabular}

Alleles of other genotypes were not significantly associated with the disease condition and GPx activity, while no associations were recorded with TR activity.

* Adjustments were made for alcohol consumption.

Serum Se levels were lower in both the malignant and benign prostate disease groups as compared with controls. Although there is controversy over the effect of Se supplementation as a prostate cancer preventative $[9,13]$, our study has shown a significant difference in serum Se level among both prostate cancer patients $(101.2 \mathrm{ng} / \mathrm{ml})$ and those with benign prostate disease $(100.7 \mathrm{ng} / \mathrm{ml})$ compared to controls $(112.9 \mathrm{ng} / \mathrm{ml})$. According to Meyer et al. [33], both serum Se and selenoprotein levels are lower among those with prostate cancer, while Steinbrecher et al. [34] have shown that the OR for prostate cancer is 0.89 for each $10-\mu \mathrm{g} / \mathrm{l}$ increment in serum Se. According to Marshall et al. [35], Se supplementation for those with high-grade prostatic intraepithelial neoplasia by way of $200 \mu \mathrm{g} /$ day selenomethionine for 3 years has produced a non-significant decrease in prostate cancer incidence only among those in the lowest tertile of plasma Se equivalent to $106 \mathrm{ng} / \mathrm{ml}$. We have previously shown that DNA damage, a possible precursor for cancer, showed an inverse relationship with increasing serum Se level up to a level of $100 \mathrm{ng} / \mathrm{ml}$. Beyond this level, there was no correlation between serum Se and DNA damage in a group of men at high risk for prostate cancer [36]. A recent study by our group has also shown benefits on DNA integrity between serum Se levels of 116 and $149 \mathrm{ng} / \mathrm{ml}$, varying with genotype, among a healthy male population [37]. Serum Se levels have been shown to positively correlate to prostate tissue Se levels [38], and therefore serum Se levels could indicate the 'seleno-nutrient health' in prostate tissue. Serum Se level is an indicator of red blood cell GPx and TR activities that are well known for their antioxidant potential [37]. Therefore, the lower levels of serum Se reported with prostate disease indicate that the disease condition accompanies oxidative stress. The current data on GPx activity levels also indicate that generally both prostate cancer patients and those with benign urology disease have significantly lower levels of GPx activity as compared to controls. This is similar to the observations made by Arsova-Sarafinovska et al. [39], indicating an increased oxidative stress in both groups. However, whether the decrease in serum Se and the accompanying oxidative stress is due to or a cause of the condition is not fully known.

Both increased and decreased levels of GPx activity with alcohol consumption have been previously reported [40-42], while the current evaluation indicates an increased GPx activity with alcohol consumption. It is possible that the increased GPx activity level recorded here 
among alcohol consumers is an adaptation to overcome the possible oxidative stress associated with this lifestyle, as suggested by Apte et al. [43].

The current study indicates that the GPx1 rs1050450 minor allele T carries a significant risk for prostate cancer. This allele was also associated with an increased GPx activity among those with prostate cancer. We have previously recorded that the GPx activity has no correlation with serum Se levels among those carrying the variant GPx1 rs 1050450 allele [37]. It is possible that the increased GPx activity among GPx1 rs1050450 allele $\mathrm{T}$ is a feature dependent on the prostate cancer pathway. A meta-analysis carried out in 14,372 cases with different tumour types and 18,081 controls derived from 31 published case-control studies has indicated that individuals with GPx1 rs1050450 CT and TT genotypes are at high risk for overall cancer incidence [20].

The current study has produced evidence that the CAT rs1001179 minor T allele is associated with a significant increase in prostate cancer risk as compared to benign prostate disease, before and after adjusting for confounding factors. Studies have indicated that the CAT rs1001179 $\mathrm{T}$ allele is associated with lower catalase activity [44-46]. Here again the $\mathrm{T}$ allele, with lower catalase activity, could be related to increased oxidative stress and instability in the cellular environment, leading to lesions and tumours. Ahn et al. [44] have reported that the difference in catalase activity between $\mathrm{CC}$ and CT+TT genotypes are further distanced with increased fruit and vegetable consumption, with those having the CC genotype recording increased levels compared to the those with the TT genotype.

Our study also reports that the SEL15 rs5845 minor allele T carries a higher risk for benign prostate disease compared to controls, while recording a lower OR of developing malignant disease compared to benign disease. The lower OR of prostate cancer as compared to benign disease associated with this allele could be due to undetected prostate cancers among the benign group. Men with urological diseases related to inflammation and subsequent bladder outlet obstruction are subjected to transurethral or open prostatectomy to relieve bladder outlet obstruction. A study of surgical specimens from such procedures has indicated that $4-16 \%$ of such patients have prostate cancer which would have gone unnoticed if surgical specimens were not available [47]. In addition, both prostate cancer and benign prostate hyperplasia have inflammation as a common denominator [48]. Therefore, identifying those with malignancies among those presenting with benign prostate disease is important in disease management. Monitoring alleles such as SEL15 rs5845 T could be a useful tool in this regard. Our studies have previously reported that the rs5845 TT genotype has a significant correlation between serum Se level and red blood cell TR activity, as well as producing higher levels of TR activity compared to the CC and CT genotypes [37]. Prostate cancer cells are in a state of redox imbalance, and, as a consequence, TR and thioredoxins are reportedly up-regulated [49-51], probably as a cancer cell-protective mechanism. It is possible that the higher TR activity level produced by rs5845 TT homozygotes supports an increased protection of cancer cells. However, Shan et al. [52] have indicated that TR activity in prostate cells diminishes with progression of prostate cancer, forming increased oxidized thioredoxin levels that get localised to the nucleus. This localisation could affect nuclear transcription factors such as p53, NFKB and NRF2 [53-55]. Kumaraswamy et al. [18] have reported that mouse liver tumours have less SEL-15, whereas mouse prostate adenocarcinoma cells have no expression compared to normal tissue. The SEL-15 gene is located in the chromosome 1 p.31 region [18], where deletions or mutations are common among many cancers, with a suggested effect on a tumour suppressor gene [56, 57].

Overall, 7 alleles (GPx1 rs1050450 allele T, GPx4 rs713041 allele C, SEPP1 rs3877899 allele A, SEL15 rs5845 allele T, SELS rs4965373 allele A, CAT rs1001179 allele T and SOD2 rs4880 allele C) tested for the GRS pointed to a significant cumulative effect on prostate cancer risk association compared to controls. Our study has not recorded significant GRS 
between prostate cancer and benign urology disease patients, or between benign urology disease patients and controls. This may be again due to the benign groups carrying undetected cancers and affecting the statistics.

We have therefore recorded the possible lifestyle factors and gene polymorphisms that may adjust the risk of prostate cancer and benign prostate disease in a cohort from Auckland, New Zealand. These risk factors mostly point to deficiencies in oxidative stress management with lifestyle factors that could get enhanced by genetic factors. Such risk factors could be used to identify subjects who could develop prostate cancer lesions among those with benign prostate disease and could enable close monitoring of at-risk subjects for better prostate cancer management practices.

\section{Acknowledgements}

We wish to thank the Auckland Medical Research Foundation, Cancer Society New Zealand, Goodfellow Trust, Urology Department, Auckland Hospital and Mad Butcher's Charitable Trust Fund, Auckland, New Zealand, for funding this study. We also wish to thank all study participants for their contribution without which we could not have achieved the outcomes.

\section{References}

1 Ministry of Health: Cancer: New registrations and deaths 2008. Wellington, New Zealand: Ministry of Health 2011.

2 Berry R, Schroeder JJ, French AJ, McDonnell SK, Peterson BJ, Cunningham JM, Thibodeau SN, Schaid DJ: Evidence for a prostate cancer-susceptibility locus on chromosome 20. Am J Hum Genet 2000;67:82-91.

3 Cooney KA, McCarthy JD, Lange E, Huang L, Miesfeldt S, Montie JE, Oesterling JE, Sandler HM, Lange K: Prostate cancer susceptibility locus on chromosome 1q: a confirmatory study. J Natl Cancer Inst 1997;89:955-959.

4 Gibbs M, Stanford JL, McIndoe RA, Jarvik GP, Kolb S, Goode EL, Chakrabarti L, Schuster EF, Buckley VA, Miller EL, Brandzel S, Li S, Hood L, Ostrander EA: Evidence for a rare prostate cancer-susceptibility locus at chromosome 1p36. Am J Hum Genet 1999;64:776-787.

5 Hsieh CL, Oakley-Girvan I, Gallagher RP, Wu AH, Kolonel LN, Teh CZ, Halpern J, West DW, Paffenbarger RS Jr, Whittemore AS: Re: prostate cancer susceptibility locus on chromosome 1q: a confirmatory study. J Natl Cancer Inst 1997;89:1893-1894.

- 6 Schaid DJ: The complex genetic epidemiology of prostate cancer. Hum Mol Genet 2004;13:R103-R121.

- 7 Xu J, Meyers D, Freije D, Isaacs S, Wiley K, Nusskern D, Ewing C, Wilkens E, Bujnovszky P, Bova GS, Walsh P, Isaacs W, Schleutker J, Matikainen M, Tammela T, Visakorpi T, Kallioniemi OP, Berry R, Schaid D, French A McDonnell S, Schroeder J, Blute M, Thibodeau S, Gronberg H, Emanuelsson M, Damber JE, Bergh A, Jonsson BA, Smith J, Bailey-Wilson J, Carpten J, Stephan D, Gillanders E, Amundson I, Kainu T, Freas-Lutz D, Baffoe-Bonnie A, Van Aucken A, Sood R, Collins F, Brownstein M, Trent J: Evidence for a prostate cancer susceptibility locus on the X chromosome. Nat Genet 1998;20:175-179.

- 8 Schmid HP, Fischer C, Engeler DS, Bendhack ML, Schmitz-Drager BJ: Nutritional aspects of primary prostate cancer prevention. Recent Results Cancer Res 2011;188:101-107.

- 9 Clark LC, Combs GF Jr, Turnbull BW, Slate EH, Chalker DK, Chow J, Davis LS, Glover RA, Graham GF, Gross EG, Krongrad A, Lesher JL Jr, Park HK, Sanders BB Jr, Smith CL, Taylor JR: Effects of selenium supplementation for cancer prevention in patients with carcinoma of the skin. A randomized controlled trial. Nutritional Prevention of Cancer Study Group. JAMA 1996;276:1957-1963.

10 Hardin J, Cheng I, Witte JS: Impact of consumption of vegetable, fruit, grain, and high glycemic index foods on aggressive prostate cancer risk. Nutr Cancer 2011;63:860-872.

$11 \mathrm{Hu}$ J, La Vecchia C, de Groh M, Negri E, Morrison H, Mery L: Dietary transfatty acids and cancer risk. Eur J Cancer Prev 2011;20:530-538.

12 Etminan M, FitzGerald JM, Gleave M, Chambers K: Intake of selenium in the prevention of prostate cancer: a systematic review and meta-analysis. Cancer Causes Control 2005;16:1125-1131.

-13 Lippman SM, Klein EA, Goodman PJ, Lucia MS, Thompson IM, Ford LG, Parnes HL, Minasian LM, Gaziano JM, Hartline JA, Parsons JK, Bearden JD 3rd, Crawford ED, Goodman GE, Claudio J, Winquist E, Cook ED, Karp DD, Walther P, Lieber MM, Kristal AR, Darke AK, Arnold KB, Ganz PA, Santella RM, Albanes D, Taylor PR, Probstfield JL, Jagpal TJ, Crowley JJ, Meyskens FL Jr, Baker LH, Coltman CA Jr: Effect of selenium and vitamin E on risk of prostate cancer and other cancers: the Selenium and Vitamin E Cancer Prevention Trial (SELECT). JAMA 2009;301:39-51. 


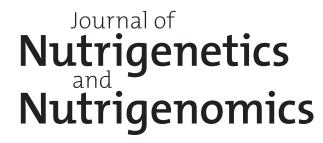

\begin{tabular}{l|l}
\hline J Nutrigenet Nutrigenomics 2012;5:339-351 \\
\hline DOI: 10.1159/000346279 & $\begin{array}{l}\text { C 2013 S. Karger AG, Basel } \\
\text { www.karger.com/jnn }\end{array}$ \\
\hline Published online: January 16, 2013 &
\end{tabular}

Karunasinghe et al.: Prostate Disease Risk Factors among a New Zealand Cohort

14 Moscow JA, Schmidt L, Ingram DT, Gnarra J, Johnson B, Cowan KH: Loss of heterozygosity of the human cytosolic glutathione peroxidase I gene in lung cancer. Carcinogenesis 1994;15:2769-2773.

15 Meplan C, Crosley LK, Nicol F, Horgan GW, Mathers JC, Arthur JR, Hesketh JE: Functional effects of a common single-nucleotide polymorphism (GPX4c718t) in the glutathione peroxidase 4 gene: interaction with sex. Am J Clin Nutr 2008;87:1019-1027.

16 Meplan C, Nicol F, Burtle BT, Crosley LK, Arthur JR, Mathers JC, Hesketh JE: Relative abundance of selenoprotein $\mathrm{P}$ isoforms in human plasma depends on genotype, se intake, and cancer status. Antioxid Redox Signal 2009;11:2631-2640.

17 Mostert V, Lombeck I, Abel J: A novel method for the purification of selenoprotein P from human plasma. Arch Biochem Biophys 1998;357:326-330.

18 Kumaraswamy E, Malykh A, Korotkov KV, Kozyavkin S, Hu Y, Kwon SY, Moustafa ME, Carlson BA, Berry MJ, Lee BJ, Hatfield DL, Diamond AM, Gladyshev VN: Structure-expression relationships of the 15-kDa selenoprotein gene. Possible role of the protein in cancer etiology J Biol Chem 2000;275:35540-35547.

-19 Curran JE, Jowett JB, Elliott KS, Gao Y, Gluschenko K, Wang J, Abel Azim DM, Cai G, Mahaney MC, Comuzzie AG, Dyer TD, Walder KR, Zimmet P, MacCluer JW, Collier GR, Kissebah AH, Blangero J: Genetic variation in selenoprotein S influences inflammatory response. Nat Genet 2005;37:1234-1241.

20 Chen J, Cao Q, Qin C, Shao P, Wu Y, Wang M, Zhang Z, Yin C: GPx-1 polymorphism (rs1050450) contributes to tumor susceptibility: evidence from meta-analysis. J Cancer Res Clin Oncol 2011;137:1553-1561.

21 HapMap: Generic genome browser version. http://hapmap.ncbi.nlm.nih.gov/cgi-perl/gbrowse/hapmap28_ B36/.

22 Rongpu Y, Jiachen H, Gongkan F, Zhengen M: Fluorometric determination of micro-amounts of selenium in human blood, using 2,3-diaminonaphthalene. Med Lab Sci 1986;43:331-334.

23 Watkinson JH: Semi-automated fluorimetric determination of nanogram quantities of selenium in biological materials. Anal Chim Acta 1979;105:319-325.

-24 Watkinson JH, Brown MW: New phase separating device and other improvements in the semi-automated fluorimetric determination of selenium. Anal Chim Acta 1979;105:451-454.

25 Karunasinghe N, Ferguson LR, Tuckey J, Masters J: Hemolysate thioredoxin reductase and glutathione peroxidase activities correlate with serum selenium in a group of New Zealand men at high prostate cancer risk. J Nutr 2006;136:2232-2235.

26 Wendel A: Glutathione peroxidase. Methods Enzymol 1981;77:325-333.

27 Smith AD, Levander OA: High-throughput 96-well microplate assays for determining specific activities of glutathione peroxidase and thioredoxin reductase. Methods Enzymol 2002;347:113-121.

28 R Development Core Team: R: A Language and Environment for Statistical Computing. Vienna, R Foundation for Statistical Computing, 2011.

-29 Leitzmann MF, Rohrmann S: Risk factors for the onset of prostatic cancer: age, location, and behavioral correlates. Clin Epidemiol 2012;4:1-11.

- 30 Braithwaite D, Boffetta P, Rebbeck TR, Meyskens F: Cancer prevention for global health: a report from the ASPO International Cancer Prevention Interest Group. Cancer Epidemiol Biomarkers Prev 2012;21:16061610.

31 International Agency for Research on Cancer (IARC): IARC Monographs on the Evaluation of Carcinogenic Risks in Human. Tobacco Smoke and Involuntary Smoking. Lyon, IARC Press, vol. 83, 2004.

-32 Rota M, Scotti L, Turati F, Tramacere I, Islami F, Bellocco R, Negri E, Corrao G, Boffetta P, La Vecchia C, Bagnardi V: Alcohol consumption and prostate cancer risk: a meta-analysis of the dose-risk relation. Eur J Cancer Prev 2012;21:350-359.

-33 Meyer HA, Hollenbach B, Stephan C, Endermann T, Morgenthaler NG, Cammann H, Kohrle J, Jung K, Schomburg L: Reduced serum selenoprotein P concentrations in German prostate cancer patients. Cancer Epidemiol Biomarkers Prev 2009;18:2386-2390.

-34 Steinbrecher A, Méplan C, Hesketh J, Schomburg L, Endermann T, Jansen E, Akesson B, Rohrmann S, Linseisen $\mathrm{J}$ : Effects of selenium status and polymorphisms in selenoprotein genes on prostate cancer risk in a prospective study of European men. Cancer Epidemiol Biomarkers Prev 2010;19:2958-2968.

35 Marshall JR, Tangen CM, Sakr WA, Wood DP Jr, Berry DL, Klein EA, Lippman SM, Parnes HL, Alberts DS, Jarrard DF, Lee WR, Gaziano JM, Crawford ED, Ely B, Ray M, Davis W, Minasian LM, Thompson IM Jr: Phase III trial of selenium to prevent prostate cancer in men with high-grade prostatic intraepithelial neoplasia: SWOG S9917. Cancer Prev Res (Phila) 2011;4:1761-1769.

-36 Karunasinghe N, Ryan J, Tuckey J, Masters J, Jamieson M, Clarke LC, Marshall JR, Ferguson LR: DNA stability and serum selenium levels in a high-risk group for prostate cancer. Cancer Epidemiol Biomarkers Prev 2004; 13:391-397.

-37 Karunasinghe N, Han DY, Zhu S, Yu J, Lange K, Duan H, Medhora R, Singh N, Kan J, Alzaher W, Chen B, Ko S, Triggs CM, Ferguson LR: Serum selenium and single-nucleotide polymorphisms in genes for selenoproteins: relationship to markers of oxidative stress in men from Auckland, New Zealand. Genes Nutr 2012;7:179-190.

-38 Takata Y, Morris JS, King IB, Kristal AR, Lin DW, Peters U: Correlation between selenium concentrations and glutathione peroxidase activity in serum and human prostate tissue. Prostate 2009;69:1635-1642.

- 39 Arsova-Sarafinovska Z, Eken A, Matevska N, Erdem O, Sayal A, Savaser A, Banev S, Petrovski D, Dzikova S, Georgiev V, Sikole A, Ozgok Y, Suturkova L, Dimovski AJ, Aydin A: Increased oxidative/nitrosative stress and decreased antioxidant enzyme activities in prostate cancer. Clin Biochem 2009;42:1228-1235. 


\section{Nutrigenetics \\ Nutrigenomics}

\begin{tabular}{l|l}
\hline J Nutrigenet Nutrigenomics 2012;5:339-351 \\
\hline $\begin{array}{l}\text { DOI: 10.1159/000346279 } \\
\text { Published online: January 26, } 2013\end{array}$ & $\begin{array}{l}\text { @ } 2013 \text { S. Karger AG, Basel } \\
\text { www.karger.com/jnn }\end{array}$ \\
\hline
\end{tabular}

40 Fernandez-Pachon MS, Berna G, Otaolaurruchi E, Troncoso AM, Martin F, Garcia-Parrilla MC: Changes in antioxidant endogenous enzymes (activity and gene expression levels) after repeated red wine intake. J Agric Food Chem 2009;57:6578-6583.

41 Peng FC, Tang SH, Huang MC, Chen CC, Kuo TL, Yin SJ: Oxidative status in patients with alcohol dependence: a clinical study in Taiwan. J Toxicol Environ Health A 2005;68:1497-1509.

$\checkmark 42$ Snook JT: Effect of ethanol use and other lifestyle variables on measures of selenium status. Alcohol 1991;8: 13-16.

43 Apte MV, Zima T, Dooley S, Siegmund SV, Pandol SJ, Singer MV: Signal transduction in alcohol-related diseases. Alcohol Clin Exp Res 2005;29:1299-1309.

44 Ahn J, Nowell S, McCann SE, Yu J, Carter L, Lang NP, Kadlubar FF, Ratnasinghe LD, Ambrosone CB: Associations between catalase phenotype and genotype: modification by epidemiologic factors. Cancer Epidemiol Biomarkers Prev 2006;15:1217-1222.

45 Bastaki M, Huen K, Manzanillo P, Chande N, Chen C, Balmes JR, Tager IB, Holland N: Genotype-activity relationship for Mn-superoxide dismutase, glutathione peroxidase 1 and catalase in humans. Pharmacogenet Genomics 2006;16:279-286.

-46 Nadif R, Mintz M, Jedlicka A, Bertrand JP, Kleeberger SR, Kauffmann F: Association of CAT polymorphisms with catalase activity and exposure to environmental oxidative stimuli. Free Radic Res 2005;39:1345-1350.

47 Zigeuner RE, Lipsky K, Riedler I, Auprich M, Schips L, Salfellner M, Pummer K, Hubmer G: Did the rate of incidental prostate cancer change in the era of PSA testing? A retrospective study of 1,127 patients. Urology 2003; 62:451-455.

48 De Nunzio C, Kramer G, Marberger M, Montironi R, Nelson W, Schroder F, Sciarra A, Tubaro A: The controversial relationship between benign prostatic hyperplasia and prostate cancer: the role of inflammation. Eur Urol 2011;60:106-117.

49 Go YM, Jones DP: Redox control systems in the nucleus: mechanisms and functions. Antioxid Redox Signal 2010;13:489-509.

50 Kumar B, Koul S, Khandrika L, Meacham RB, Koul HK: Oxidative stress is inherent in prostate cancer cells and is required for aggressive phenotype. Cancer Res 2008;68:1777-1785.

51 Mukherjee A, Martin SG: The thioredoxin system: a key target in tumour and endothelial cells. Br J Radiol 2008; 81:S57-S68.

52 Shan W, Zhong W, Zhao R, Oberley TD: Thioredoxin 1 as a subcellular biomarker of redox imbalance in human prostate cancer progression. Free Radic Biol Med 2010;49:2078-2087.

53 Hansen JM, Go YM, Jones DP: Nuclear and mitochondrial compartmentation of oxidative stress and redox signaling. Annu Rev Pharmacol Toxicol 2006;46:215-234.

54 Hayashi T, Ueno Y, Okamoto T: Oxidoreductive regulation of nuclear factor kappa B. Involvement of a cellular reducing catalyst thioredoxin. J Biol Chem 1993;268:11380-11388.

55 Schafer FQ, Buettner GR: Redox environment of the cell as viewed through the redox state of the glutathione disulfide/glutathione couple. Free Radic Biol Med 2001;30:1191-1212.

56 Cheung TH, Chung TK, Poon CS, Hampton GM, Wang VW, Wong YF: Allelic loss on chromosome 1 is associated with tumor progression of cervical carcinoma. Cancer 1999;86:1294-1298.

57 Nagai H, Negrini M, Carter SL, Gillum DR, Rosenberg AL, Schwartz GF, Croce CM: Detection and cloning of a common region of loss of heterozygosity at chromosome 1p in breast cancer. Cancer Res 1995;55:1752-1757. 